\title{
Ammonia tolerant inocula provide a good base for anaerobic digestion of microalgae in third generation biogas process
}

\author{
Mahdy, Ahmed; Fotidis, loannis; Mancini, Enrico; Ballesteros, Mercedes
}

Published in:

Bioresource Technology

Link to article, DOI:

10.1016/j.biortech.2016.11.086

Publication date:

2017

Document Version

Peer reviewed version

Link back to DTU Orbit

Citation (APA):

Mahdy, A., Fotidis, I., Mancini, E., \& Ballesteros, M. (2017). Ammonia tolerant inocula provide a good base for anaerobic digestion of microalgae in third generation biogas process. Bioresource Technology, 225, 272-278. https://doi.org/10.1016/i.biortech.2016.11.086

\section{General rights}

Copyright and moral rights for the publications made accessible in the public portal are retained by the authors and/or other copyright owners and it is a condition of accessing publications that users recognise and abide by the legal requirements associated with these rights.

- Users may download and print one copy of any publication from the public portal for the purpose of private study or research.

- You may not further distribute the material or use it for any profit-making activity or commercial gain

- You may freely distribute the URL identifying the publication in the public portal 


\section{Ammonia tolerant inocula provide a good base for anaerobic}

\section{digestion of microalgae in third generation biogas process}

Ahmed Mahdy a,b ${ }^{\mathrm{a}}$, Ioannis A. Fotidis ${ }^{\mathrm{c}^{*}}$, Enrico Mancini ${ }^{\mathrm{c}}$, Mercedes

Ballesteros $^{\mathrm{a}, \mathrm{d}}$, Cristina González-Fernández ${ }^{\mathrm{a}}$, Irini Angelidaki ${ }^{\mathrm{c}}$

${ }^{a}$ Biotechnological Processes for Energy Production Unit - IMDEA Energy, 28935

Móstoles, Madrid, Spain

${ }^{\mathrm{b}}$ Department of Agricultural Microbiology, Faculty of Agriculture, Zagazig University, 44511 Zagazig, Egypt

${ }^{\mathrm{c}}$ Department of Environmental Engineering, Technical University of Denmark, Bygningstorvet Bygning 115, DK-2800 Kgs. Lyngby, Denmark

${ }^{\mathrm{d}}$ Biofuels Unit - Research Center for Energy, Environment and Technology

(CIEMAT), 28040 Madrid, Spain

* Corresponding Author: Ioannis A. Fotidis, Department of Environmental Engineering, Technical University of Denmark, DK-2800 Kgs. Lyngby, Denmark, Phone: (+45)

45251418; Fax: (+45) 45933850; e-mail: ioanf@env.dtu.dk 


\section{Abstract}

This study investigated the ability of an ammonia-acclimatized inoculum to digest efficiently protein-rich microalgae for continuous $3^{\text {rd }}$ generation biogas production. Moreover, we investigated whether increased $\mathrm{C} / \mathrm{N}$ ratio could alleviate ammonia toxicity. The biochemical methane potential (BMP) of five different algae (Chlorella vulgaris)/manure (cattle) mixtures showed that the mixture of 80/20 (on VS basis) resulted in the highest BMP value $\left(431 \mathrm{~mL} \mathrm{CH}_{4} \mathrm{~g} \mathrm{VS}^{-1}\right)$, while the BMP of microalgae alone (100/0) was $415 \mathrm{~mL} \mathrm{CH}_{4} \mathrm{~g} \mathrm{VS}^{-1}$. Subsequently, anaerobic digestion of those two substrates was tested in continuous stirred tank reactors (CSTR). Despite of the high ammonium levels (3.7-4.2 $\left.\mathrm{g} \mathrm{NH}_{4}^{+}-\mathrm{N} \mathrm{L}^{-1}\right)$, CSTR reactors using ammonia tolerant inoculum resulted in relatively high methane yields (i.e. $77.5 \%$ and $84 \%$ of the maximum expected, respectively) These results demonstrated that ammonia tolerant inocula could be a promising approach to successfully digest protein-rich microalgae and achieve a $3^{\text {rd }}$ generation biogas production.

Keywords: Ammonia inhibition; Anaerobic digestion; BMP; Co-digestion; Microalgae. 


\section{Introduction}

A great effort has been dedicated to the development of green technologies for producing renewable biofuels. Conversion of organic matter into biogas through anaerobic digestion (AD) has been intensely investigated since, unlike bioethanol or biodiesel, it holds the possibility to convert a broad variety of organic substrate to biogas (Naik et al., 2010). However, deeper understanding is required to address several challenges that can affect performance and stability of the conversion process when using new feedstocks. Microalgae, for example, seem to be a promising candidate for AD since they guarantee sustainable flow of feedstock without compromising world food supplies (Maity et al., 2014). Thus, microalgae are classified as $3^{\text {rd }}$ generation biogas feedstocks (Allen et al., 2016). Nevertheless, microalgae exhibit a typical low $\mathrm{C} / \mathrm{N}$ ratio due to their high protein content (Yen and Brune, 2007; Mahdy et al., 2015a). During metabolism of nitrogenous organic matter (mostly proteins in the case of microalgae), total ammonia (ammonium ion + free ammonia) is released. Low levels of total ammonia are important for the proper growth of the anaerobic flora and for the establishment of sufficient pH buffer capacity in the AD process (Kayhanian, 1999). However, higher ammonia levels might inhibit the AD process (Rajagopal et al., 2013). There is controversial information in the literature about the toxicity threshold of ammonia for the AD process. This could be attributed that many factors, such as digestion conditions (e.g. $\mathrm{pH}$, temperature), nature and origin of substrates and inocula are influencing the toxicity of ammonia. As a consequence of that, toxic ammonia threshold ranges from 1.7 up to $14 \mathrm{~g} \mathrm{NH}_{4}{ }^{+}-\mathrm{N} \mathrm{L}^{-1}$ have been reported (Chen et al., 2008). Additionally, free ammonia (i.e. the most toxic form of ammonia for the AD process), increases its concentration alongside with $\mathrm{pH}$ and temperature and that adds to the 
complexity of ammonia toxicity (Rajagopal et al., 2013). Today, it is broadly accepted that total ammonia and free ammonia concentrations over $3 \mathrm{~g} \mathrm{NH}_{4}{ }^{+}-\mathrm{N} \mathrm{L}^{-1}$ or $0.15 \mathrm{~g}$ $\mathrm{NH}_{3}-\mathrm{N} \mathrm{L}^{-1}$, respectively are toxic for methanogenesis independently of temperature and pH levels (Chen et al., 2008).

Several methods to counteract ammonia inhibition in AD process have been proposed in literature. In this line, dilution of feeding streams (Webb and Hawkes, 1985), air stripping (Wu et al., 2016), bioaugmentation (Fotidis et al., 2014b), codigestion (Yen and Brune, 2007), ammonia binding ions (Fotidis et al., 2014a) and struvite precipitation (Nelson et al., 2003) have been studied. Even though, some of them have been proven successful, they are still cost-expensive and/or pose technical challenges for full-scale implementation. Moreover, most of these methods have been conducted in $1^{\text {st }}$ and $2^{\text {nd }}$ generation biogas production with conventional substrates while microalgae as a feedstock, still deserves further investigation.

A potential strategy to circumvent the challenges that the aforementioned methods pose is to use anaerobic inocula already acclimatized to high ammonia concentrations and/or increase the $\mathrm{C} / \mathrm{N}$ ratio of the substrate by mixing microalgae with another substrate (co-digestion)(Herrmann et al., 2016). Most of the researches performed nowadays about the $\mathrm{AD}$ of microalgae, use inocula (i.e. wastewater treatment plant sludge and cattle manure based inocula) that have low ammonia tolerance (SantosBallardo et al., 2016). These anaerobic inocula originate from processes, in which ammonia levels were typically lower than $2 \mathrm{~g} \mathrm{NH}_{4}{ }^{+}-\mathrm{N} \mathrm{L}^{-1}$ (Serrano et al., 2016) and thus, the methanogenic microbial populations cannot cope with the high protein loads of the microalgae substrate. For example, Mahdy et al. (2015b) evaluated the performance of anaerobic sludge in a continuous stirred tank reactor (CSTR) fed with protein-rich 
microalgae. Their results showed decrease on methane yield concomitantly with accumulation of VFA concentration, indicating inhibition due to ammonia toxicity (> $\left.2.9 \mathrm{~g} \mathrm{NH}_{+}{ }^{4}-\mathrm{N} \mathrm{L}^{-1}\right)$. These results raise questions about the suitability of protein-rich microalgae as potential feedstock for $3^{\text {rd }}$ generation biogas production.

Therefore, the overall aim of the present study was to investigate if an ammoniaacclimatized inoculum could efficiently digest protein-rich microalgae for continuous $3^{\text {rd }}$ generation biogas production. A secondary aim was to assess if the acclimatized inoculum combined with the improvement of the $\mathrm{C} / \mathrm{N}$ ratio of the microalgae with the addition of a co-substrate with typical ammonia content (i.e. cattle manure) could alleviate further the ammonia toxicity effect. In order to achieve these aims, two different experiments were conducted. In the first experiment, the biochemical methane potential (BMP) of the microalgae, the cattle manure and their different co-digestion mixtures were assessed and thus, the best co-digestion mixture was identified. In the second experiment, an ammonia-acclimatized inoculum was used in CSTR reactors fed only with microalgae (mono-digestion, $3^{\text {rd }}$ generation biogas production) or with the best mixture of microalgae and cattle manure (co-digestion, $2^{\text {nd }}$ generation biogas production).

\section{Material and methods}

\subsection{Inocula}

A thermophilic inoculum $\left(55 \pm 1^{\circ} \mathrm{C}\right)$ obtained from manure based Snertinge biogas plant (Denmark) was used for the BMP assays. The inoculum was incubated for ten days before use to minimize the indigenous biogas production. An ammonia acclimatized $\left(>4.5 \mathrm{~g} \mathrm{NH}_{4}{ }^{+}-\mathrm{N} \mathrm{L}^{-1}\right)$ mesophilic inoculum $\left(37 \pm 1^{\circ} \mathrm{C}\right)$, obtained from a 
manure based full-scale reactor (Hashøj Biogas, Denmark), was used in the CSTR reactors' experiments. The chemical characteristics of both inocula are presented in Table 1.

\subsection{Substrates}

\subsubsection{Microalgae}

Chlorella vulgaris was used as the protein-rich microalgae model. This biomass was grown in mineral salt (MBBM-2N) medium (Mendez et al., 2013). C. vulgaris was cultured in a raceway, with a working volume of $150 \mathrm{~L}$, with continuous illumination at $25^{\circ} \mathrm{C}$. In order to provide light homogenously and avoid concentration gradients, culture mixing was conducted using paddle wheels. Microalgae biomass was harvested twice a week with a centrifuge (Westfalia Separator, Model OTC3-02-137, Germany). Once harvested, microalgae biomass was pretreated according to Mahdy et al. (2015b). Specifically, a protease (Alcalase 2.5, Novozymes, Denmark) was used (2.5 mL Alcalase $\mathrm{g}^{-1}$ algae DW) as biological catalyst to hydrolyse $C$. vulgaris prior to the AD. Subsequently, the hydrolytic broth was upconcentrated to 60-70 g microalgae biomass $\mathrm{L}^{-1}$ (total solids) prior to enzymatic hydrolysis and the $\mathrm{pH}$ was adjusted to 8 throughout the pretreatment. The hydrolysates were heated to $75^{\circ} \mathrm{C}$ for 30 minutes to deactivate the enzymes after three hours of pretreatment. After the volatile solids (VS) were adjusted with the addition of deionized water (Table 1), pretreated microalgae were stored in the freezer until use.

\subsubsection{Manure}

The raw cattle manure used in the experiment was obtained from Hashøj biogas plant, Denmark. The manure was sieved $(5 \mathrm{~mm})$, to separate large particles, to avoid clogging of the tubes, mixed and stored at $-21^{\circ} \mathrm{C}$. The frozen manure was thawed at $4{ }^{\circ} \mathrm{C}$ 
for 1-2 days before use. The basic characteristics of cattle manure are also presented in Table 1.

\subsection{BMP assays experimental setup}

All the BMP experiments were performed in glass serum bottles with 60 and 320 $\mathrm{mL}$ working and total volume, respectively and substrate/inoculum (S/I) ratio of 20/80 (on VS basis) (Angelidaki et al., 2009). As shown in Table 2, two mono-substrates (microalgae and manure) and five different co-substrate mixtures (microalgae/manure on VS basis) were tested to determine their BMP. Two different organic loads were assessed in all BMP experiments to avoid any possible organic overloading or other potential inhibition, which might result in underestimation of the methane potential. Additionally, blank reactors (only inoculum and water) were used to quantify the background methane production of the inoculum and control reactors (with Avicel® PH-101, Sigma Aldrich as added carbon source) were used to verify the optimum methanogenic activity of the inoculum. In these terms, the BMP value of the control substrate was measured close to the theoretical (414 $\mathrm{NmL} \mathrm{CH}_{4} \mathrm{~g}^{-1} \mathrm{VS}$ ), which supports the accuracy of the BMP assay procedure (Holliger et al., 2016). After inoculation, all BMP reactors were flushed with $\mathrm{N}_{2}: \mathrm{CO}_{2}(80: 20 \% \mathrm{v} / \mathrm{v})$, sealed with butyl rubber stoppers and inoculated under thermophilic conditions $\left(55 \pm 1^{\circ} \mathrm{C}\right)$. All experiments were performed in triplicates, run for at least one month, and the methane production presented for each reactor was normalized (in $\mathrm{NmL}$ ) to the standard temperature and pressure (i.e. $273.15 \mathrm{~K}$ and $1013.25 \mathrm{hPa}$ ) conditions. 


\subsection{CSTR experimental setup}

The continuous experiments were performed in four identical glass lab-scale CSTR reactors operated at mesophilic temperature $\left(37 \pm 1^{\circ} \mathrm{C}\right)$. The reactors had 2.3 and $1.8 \mathrm{~L}$ total and working volume, respectively. Each reactor consisted of a peristaltic pump, a heating jacket, a feeding vessel, an effluent bottle, two magnetic stirrers for the homogenization of substrate and mixing of the reactor and a water-displacement gas meter. The experiment consisted of two phases, differentiated by the substrate, organic loading rate (OLR) and ammonia levels in the feedstock (Table 3). During Phase-I all reactors were fed only with cattle manure while during Phase-II reactors $R_{1}$ and $R_{2}$ were fed only with the microalgae (mono-digestion) and reactors $\mathrm{R}_{3}$ and $\mathrm{R}_{4}$ with the microalgae and manure mixture (co-digestion). The hydraulic retention time (HRT) was 23 days for all reactors and the feeding was performed twice per day by controlled pump. Taking into account that the ammonia concentration in the CSTR reactors was changing throughout the experiment, the exact total ammonia levels in the CSTR reactors are presented in Fig. S1 (Supplementary Material).

\subsection{Analytical methods}

Total solid (TS), volatile solids (VS), total Kjeldahl nitrogen (TKN) and ammonia were measured according to Standard Methods (APHA, 2005). The pH fluctuation in the CSTR reactors was measured with PHM99 LAB pH meter. VFAs concentration was determined with a gas-chromatograph (HP 5890 series II) equipped with flame ionization detector (FID) and a FFAP fused silica capillary column $(30 \mathrm{~m} \times 0.53 \mathrm{~mm}$ i.d., film thickness $1.5 \mu \mathrm{m}$ ), with nitrogen as carrier gas. Methane content in BMP experiments was measured with a thermo-scientific trace gas-chromatograph (TRACE 1310) equipped with a FID and a bonded polystyrene-divinylbenzene (Agilent J\&W 
HP-PLOT Q is $)$ column $(8 \mathrm{~m} \times 0.32 \mathrm{~mm}$ i.d., film thickness $20 \mu \mathrm{m})$. Helium was the carrier gas, the oven temperature was set at $160^{\circ} \mathrm{C}$ and the instrument method used was SOP SSL FID. Gas composition in CSTR reactors' headspace was determined by gas chromatography equipped with a column of $1.1 \mathrm{~m} \times 3 / 16$ "Molsieve 137 and $0.7 \mathrm{~m} \times$ 1/4" chromosorb 108 (MGC 82-12, Mikrolab A/S, Denmark).

\subsection{Calculations and statistical analyses}

All statistical analyses were made using the Graphpad PRISM program (Graphpad Software, Inc., San Diego, California). Analysis of variance (one-way ANOVA), for statistically significant difference $(p<0.05)$, was used for methane production and VFA accumulation of the CSTR reactors. Dixon's test was used to eliminate a single outlier from triplicate measurements of BMP. Student's t-test for statistically significant difference $(p<0.05)$ was used for the BMP experiments. The co-digestion effect was determined based on BMP values of mono-substrates (microalgae and manure) tested. The maximum expected methane productions of the CSTR reactors were calculated based on the BMP values of the mono-substrates and compared with the obtained methane production. Methane production yield and rate at the different steady states of the CSTR reactors was calculated as the average methane production during steady state period. Ten successive operation days, with less than $10 \%$ variation in methane yield/rate, VFA and pH was defined as steady state (Hansen et al., 1998). All values presented are the means of independent triplicates $(n=3) \pm S$. 


\section{Results and discussion}

\subsection{BMP of mono- and co-substrates}

The BMP value of microalgae was $415 \mathrm{NmL} \mathrm{CH}_{4} \mathrm{~g}^{-1}$ VS (Fig. 1a). This methane yield is similar to values previously reported by Mahdy et al. (2014) for the same protease pretreated microalgae. It is known that microalgae have a hard cell wall that hamper the hydrolysis stage (González-Fernández et al., 2012). However, when microalgae are subjected to enzymatic pretreatment prior to $\mathrm{AD}$, the hydrolysate becomes easy to attack by anaerobic microorganisms and higher methane yields are attained as Ometto et al. (2014) have reported. On the other hand, BMP values of cattle manure ranged 297-339 $\mathrm{NmL} \mathrm{CH}_{4} \mathrm{~g}^{-1} \mathrm{VS}$. This BMP value was at the higher end of the values reported in the literature (El-Mashad and Zhang, 2010; Strömberg et al., 2014). This could be attributed to the quality of the specific manure and to the fact that the largest fibers, which are also the most recalcitrant, were sieved away to avoid clogging of the tubes. Regardless the substrate type, the results showed similarity in methane yields between organic loads tested, indicating the absence of negative effect due to overloading or content of inhibitors. The final accumulated methane production for microalgae and cattle manure determined by BMP assays can be seen in Fig. S2 (Supplementary Material).

Among all mixtures tested in BMP assay (Fig. 1b), the co-digestion mixtures with the statistically highest $(\mathrm{p}<0.05)$ BMP values $\left(>420 \mathrm{NmL} \mathrm{CH}_{4} \mathrm{~g}^{-1} \mathrm{VS}\right)$ were microalgae/manure: 80/20 (OL: $2.33 \mathrm{VS} \mathrm{g} \mathrm{L}^{-1}$ ) and 60/40 (OL: 2.33 and $4.66 \mathrm{VS} \mathrm{g} \mathrm{L}^{-1}$ ). In contrast, the mixtures that had statistically the lowest and, at the same time, similar, BMP values (<325 $\left.\mathrm{NmL} \mathrm{CH}_{4} \mathrm{~g}^{-1} \mathrm{VS}\right)$ were 20/80 (OL: 2.33 and $\left.4.66 \mathrm{VS} \mathrm{g} \mathrm{L}^{-1}\right)$ and 
40/60 OL (OL: 4.66 VS g L ${ }^{-1}$ ). These results indicated that co-digestion mixtures, which had higher proportion of microalgae (especially those with higher than $60 \%$ in VS basis), exhibited higher methane yields compared to co-digestion mixtures with higher proportion of cattle manure. This trend could be attributed to the higher biodegradability displayed by microalgae biomass compared to manure (Fig. 1a). The biodegradability of microalgae was enhanced by the enzymatic pretreatment (Mahdy et al., 2014), making the organic matter available for microbial degradation while, the possible inhibitory effect of the released ammonia during hydrolysis of the contained proteins would not have any effect due to the dilution effect caused by the large amount of inoculum. On the contrary, manure has high content of recalcitrant substances and thereby, relatively low methane potential (El-Mashad and Zhang, 2010; Frear et al., 2011) compared to microalgae.

The methane yields achieved by microalgae/manure: 80/20 (OL: $2.33 \mathrm{VS} \mathrm{g} \mathrm{L}^{-1}$ ), 60/40 (OL: 2.33 and 4.66 VS g L $\left.{ }^{-1}\right)$ mixtures were statistically higher $(\mathrm{p}<0.05)$ compared to the expected values as calculated by the methane yields of monosubstrates, indicating synergistic co-digestion effect (Fig. 1c). On the contrary, negative or negligible co-digestion effects were observed for all the other mixtures. These results imply that, although cattle manure has lower nitrogen content than microalgae, the $\mathrm{C} / \mathrm{N}$ ratio of the mixture seems to be still low and hence, the co-digestion process supported only a slightly synergistic effect (8-15\%). In fact, several studies have highlighted a profound synergistic effect when either microalgae or cattle manure was co-digested with other substrates. For instance, Ramos-Suárez et al. (2014) reported higher methane yields $(64 \%)$ compared to digestion of single substrates when microalgae were codigested with cactus species Opuntia maxima at mixture of 25/75 (on VS basis). On the 
other hand, the synergetic effect of cattle manure has been shown in numerous investigations such as when manure was co-digested with pretreated wheat straw (Song and Zhang, 2015) and food waste (Zhang et al., 2013). These studies have attributed the synergistic effect to the suitable $\mathrm{C} / \mathrm{N}$ ratio achieved with the mixtures. Therefore, current results imply that in order to have a profound synergistic effect while codigesting microalgae, a co- substrate with high $\mathrm{C} / \mathrm{N}$ ratio is necessary. Finally, based on the BMP value and the synergistic effect, along with microalgae (mono-substrate), 80/20 mixture (co-substrate) was chosen for further assessment under continuous mode.

\subsection{Continuous mono- and co-digestion}

\subsubsection{Performance of CSTR experiments}

Phase-I of CSTR reactors operation was used as the baseline for the determination of any changes in the methane production performance of the reactors during Phase-II.

Thus, during Phase-I all four reactors were at steady state with average methane yield of $211 \pm 6 \mathrm{NmL} \mathrm{CH}_{4} \mathrm{~g} \mathrm{VS}^{-1}$ (Fig. 2). This was an expected methane production for continuous $\mathrm{AD}$ of cattle manure, derived from the same source as has been reported before (Fotidis et al., 2014b).

From day 43 (phase II), microalgae was fed in CSTRs reactors and the methane yield of all reactors remained stable for approximately ten days before it started to increase rapidly (day 54). During this period, the relative methane production, calculated from BMP values of the two mono-substrates, was only $47 \%$ of the maximum expected one, based on the BMP values. In comparison, the relative methane production in Phase-I (under steady state, days 15-43) was approximately $65 \%$ of the maximum expected based on the BMP tests. 
The most possible reason for the observed lag phase with suboptimal methane production was due to change of feedstock (Table 1). The different feedstocks could had affected the microbial population dynamic of anaerobic process (De Francisci et al., 2015). Alternatively, microorganism would need time to adapt their metabolism to the new substrates. In any case, the anaerobic microbial communities needed some time to adapt to the new feedstocks and once this happened, the methane production increased drastically up to $430 \mathrm{NmL} \mathrm{CH}_{4} \mathrm{~g}^{-1} \mathrm{VS}$ (days 53-65), in all four reactors. This methane yield was significantly higher $(\mathrm{p}<0.05)$ than the maximum expected methane productions (415 and $400 \mathrm{NmL} \mathrm{CH}_{4} \mathrm{~g}^{-1} \mathrm{VS}$ for mono- and co digestion, respectively) calculated based on the BMP results. This brief shout over period was the result of the previous period of low substrate utilization, which increased the undigested organic fraction of the reactors. When the microbes adapted to the new substrates, the available biomass was catabolized rapidly.

The methane production of the reactors was gradually decreased after day 56 until a new steady state (days 67-92) was established, with $81.5 \%$ and $77 \%$ of the maximum expected yield for co- and mono-digestion reactors, respectively. Both reactors showed remarkable ability to digest the two substrates. Nevertheless, co-digestion reactors had statistically higher relative methane production than mono-digestion reactors, indicating a small but positive synergistic effect of co-digestion process. The lower ammonia concentration in co-digestion reactors compared with that in mono-digestion reactors (3.8 $\mathrm{g} \mathrm{NH}_{4}{ }^{+}-\mathrm{N} \mathrm{L}^{-1}$ vs $4.2 \mathrm{NH}_{4}{ }^{+}-\mathrm{N} \mathrm{L}^{-1}$, Fig. S1, due to lower nitrogen content of cattle manure compared to microalgae) could explain the better performance of co-digestion reactors. In general, even though it was proposed that ammonia levels above $3 \mathrm{~g} \mathrm{NH}_{4}{ }^{+}-$ $\mathrm{N} \mathrm{L}^{-1}$ have a toxic effect on the AD process (Parkin and Owen, 1986), all reactors were 
operating at steady state, with high relative methane yields (days 65 to 90 days). These results are supported by Nakakubo et al. (2008), who showed that exposure to high nitrogen levels increases methanogens resistant to high ammonia levels.

\subsubsection{VFA accumulation and $\mathrm{pH}$ fluctuation}

The total VFA concentrations in all the CSTR reactors during the steady state of Phase-I, were below $1 \mathrm{~g} \mathrm{HAc} \mathrm{L}^{-1}$ indicating an efficient AD process (Fig. 3). Specifically, it has been established before that $1.5 \mathrm{~g} \mathrm{HAc} \mathrm{L}^{-1}$ is the threshold for a healthy AD process in manure-based CSTR reactors (Boe et al., 2010). However, immediately after the addition of microalgae in the feedstocks, VFA were accumulated in all four reactors up to $4.3 \mathrm{~g} \mathrm{HAc} \mathrm{L}^{-1}$. This accumulation was concomitant with a reduced methane productivity after adding microalgae (42-52 days, Fig S3 and Fig 3). As it was explained, this was an ephemeral symptom and is most probably attributed to time that the microorganisms needed to adapt to the new feedstocks. Once anaerobic microorganisms have adapted to the new conditions, the VFAs decreased to even lower levels than those obtained during Phase-I, with an average of $0.65 \mathrm{~g} \mathrm{HAc} \mathrm{L}^{-1}$. The low VFA concentrations during the new steady state (days 70-90) implied good process stability.

In exception of days between 43-50, where $\mathrm{pH}$ was between 7.7 and 8.0 due to VFA accumulation, the $\mathrm{pH}$ for all reactors remained between 8 and 8.3 throughout the experiment (Fig. 3). Nevertheless, $\mathrm{pH}$ levels remained inside the permissible range for continuous AD process which is between 6.5 and 8.4 (Yi et al., 2014).

\subsubsection{Acclimatized versus non-acclimatized inocula}

Ammonia inhibition was observed previously when using un-acclimatized inocula to digest enzymatically pretreated protein-rich microalgae in CSTR reactors (Mahdy et 
al., 2015). Specifically, a reduction of methane production rate was reported at ammonia concentration of just $1.9 \mathrm{~g} \mathrm{NH}_{4}{ }^{+}-\mathrm{N} \mathrm{L}^{-1}$ (Mahdy et al., 2015b), which led to process failure. In an attempt to solve the ammonia inhibition problem, the same researchers reduced the protein content of their feedstock by cultivating the microalgae under nutrient limitation conditions, and thus carbohydrates were accumulated (Mahdy et al., 2016). However, CSTR reactors fed with enzymatically pretreated carbohydrate-rich microalgae at only $0.86 \mathrm{~g} \mathrm{NH}_{4}{ }^{+}-\mathrm{N} \mathrm{L}^{-1}$, achieved maximum $58 \%$ of the relative methane production compared to the maximum expected production. This means that ammonia tolerant inocula used in the current study were $33 \%$ more effective in utilizing the methanogenic potential of microalgae biomass, compared to the reactors operating with non-acclimatized inocula and fed with protein poor biomass. Therefore, operating reactors with ammonia tolerant inocula seems to be a promising approach to achieve efficient digestion of protein-rich microalgae and paves the way for further research on $3^{\text {rd }}$ generation biogas production.

\section{Conclusions}

In previous studies protein-rich microalgae led to ammonia inhibition when used as anaerobic substrates. In this study was shown that, protein-rich microalgae biomass is an easily degradable substrate with high methane potential. Additionally, it was proven that operating CSTR reactors with ammonia tolerant inocula could efficiently digest protein-rich microalgae. This approach provided stable digester performance and high methane yields at high ammonia concentrations (up to $4.2 \mathrm{~g} \mathrm{NH}_{4}{ }^{+}-\mathrm{N} \mathrm{L}^{-1}$ ). Moreover, further improvement could arise when microalgae was co-digested with high $\mathrm{C} / \mathrm{N}$ ration substrates. Therefore, using ammonia tolerant inocula is a promising solution and an easily applicable approach to digest commercially protein-rich microalgae. 


\section{Acknowledgements}

This work was supported by Energinet.dk under the project framework ForskEL "MicrobStopNH $\mathrm{N}_{3}$-Innovative bioaugmentation strategies to tackle ammonia inhibition in anaerobic digestion process" (program no. 2015-12327) and the Spanish Ministry of Economy and Competitiveness for financial support to projects of (WW-ALGAS, ENE2013-45416-R and RYC-2014-16823). We would also like to acknowledge the Community of Madrid for the support offered in the framework of the project INSPIRA-1 (S2013/ABI-2783). The authors would like to extend their gratitude to Novozymes-Denmark.

\section{References}

1 Allen, E., Wall, D.M., Herrmann, C., Murphy, J.D., 2016. A detailed assessment of resource of biomethane from first, second and third generation substrates. Renewable Energy 87, 656-665.

2 Angelidaki, I., Alves, M., Bolzonella, D., Borzacconi, L., Campos, J.L., Guwy, A.J., Kalyuzhnyi, S., Jenicek, P., van Lier, J.B., 2009. Defining the biomethane potential (BMP) of solid organic wastes and energy crops: a proposed protocol for batch assays. Water Sci. Technol. 59, 927-34.

APHA, 2005. Standard methods for the examination of water and wastewater. $21^{\text {th }}$ ed. American Public Health Association, Washington, DC.

4 Boe, K., Batstone, D.J., Steyer, J.P., Angelidaki, I., 2010. State indicators for monitoring the anaerobic digestion process. Water Res. 44, 5973-80.

5 Chen, Y., Cheng, J.J., Creamer, K.S., 2008. Inhibition of anaerobic digestion process: a review. Bioresour. Technol. 99, 4044-64. 
El-Mashad, H.M., Zhang, R., 2010. Biogas production from co-digestion of dairy manure and food waste. Bioresour. Technol. 101, 4021-4028.

7 Fotidis, I.A., Kougias, P.G., Zaganas, I.D., Kotsopoulos, T.A., Martzopoulos, G.G., 2014a. Inoculum and zeolite synergistic effect on anaerobic digestion of poultry manure. Environ. Technol. 35, 1219-25.

8 Fotidis, I.A., Wang, H., Fiedel, N.R., Luo, G., Karakashev, D.B., Angelidaki, I., 2014b. Bioaugmentation as a Solution To Increase Methane Production from an Ammonia-Rich Substrate. Environ. Sci. Technol. 48, 7669-7676.

9 Frear, C., Wang, Z.W., Li, C., Chen, S., 2011. Biogas potential and microbial population distributions in flushed dairy manure and implications on anaerobic digestion technology. J. Chem. Technol. Biotechnol. 86, 145-152.

10 González-Fernández, C., Sialve, B., Bernet, N., Steyer, J.P., 2012. Impact of microalgae characteristics on their conversion to biofuel. Part II: Focus on biomethane production. Biofuels, Bioprod. Biorefin. 6, 205-218.

11 Hansen, K.H., Angelidaki, I., Ahring, B.K., 1998. Anaerobic digestion of swine manure: inhibition by ammonia. Water Res. 32, 5-12.

12 Herrmann, C., Kalita, N., Wall, D., Xia, A., Murphy, J.D., 2016. Optimised biogas production from microalgae through co-digestion with carbon-rich cosubstrates. Bioresour. Technol. 214, 328-337.

13 Holliger, C., Alves, M., Andrade, D., Angelidaki, I., Astals, S., Baier, U., Bougrier, C., Buffière, P., Carballa, M., de Wilde, V., Ebertseder, F., Fernández, B., Ficara, E., Fotidis, I., et al., 2016. Towards a standardization of biomethane potential tests. Water Sci. Technol., in press. 
14 Kayhanian, M., 1999. Ammonia inhibition in high-solids biogasification: An overview and practical solutions. Environ. Technol. 20, 355-365.

15 Mahdy, A., Mendez, L., Ballesteros, M., Gonzalez-Fernandez, C., 2015a. Algaculture integration in conventional wastewater treatment plants: anaerobic digestion comparison of primary and secondary sludge with microalgae biomass. Bioresour. Technol. 184, 236-44.

16 Mahdy, A., Mendez, L., Ballesteros, M., Gonzalez-Fernandez, C., 2014.

Enhanced methane production of Chlorella vulgaris and Chlamydomonas reinhardtii by hydrolytic enzymes addition. Energy Convers. Manage. 85, 551557.

17 Mahdy, A., Mendez, L., Ballesteros, M., Gonzalez-Fernandez, C., $2015 b$.

Protease pretreated Chlorella vulgaris biomass bioconversion to methane via semi-continuous anaerobic digestion. Fuel 158, 35-41.

18 Maity, J.P., Bundschuh, J., Chen, C.-Y., Bhattacharya, P., 2014. Microalgae for third generation biofuel production, mitigation of greenhouse gas emissions and wastewater treatment: Present and future perspectives - A mini review. Energy $78,104-113$.

19 Mendez, L., Mahdy, A., Timmers, R.A., Ballesteros, M., Gonzalez-Fernandez, C., 2013. Enhancing methane production of Chlorella vulgaris via thermochemical pretreatments. Bioresour. Technol. 149, 136-41.

20 Naik, S.N., Goud, V.V., Rout, P.K., Dalai, A.K., 2010. Production of first and second generation biofuels: A comprehensive review. Renewable Sustainable Energy Rev. 14, 578-597. 
21 Nakakubo, R., Moller, H.B., Nielsen, A.M., Matsuda, J., 2008. Ammonia Inhibition of Methanogenesis and Identification of Process Indicators during Anaerobic Digestion. Environ. Eng. Sci. 25, 1487-1496.

22 Nelson, N.O., Mikkelsen, R.L., Hesterberg, D.L., 2003. Struvite precipitation in anaerobic swine lagoon liquid: effect of $\mathrm{pH}$ and $\mathrm{Mg}: \mathrm{P}$ ratio and determination of rate constant. Bioresour. Technol. 89, 229-236.

23 Ometto, F., Quiroga, G., Pšenička, P., Whitton, R., Jefferson, B., Villa, R., 2014. Impacts of microalgae pre-treatments for improved anaerobic digestion: thermal treatment, thermal hydrolysis, ultrasound and enzymatic hydrolysis. Water Res. $65,350-361$.

24 Parkin, G.F., Owen, W.F., 1986. Fundamentals of anaerobic digestion of wastewater sludges. J. Environ. Eng. 112, 867-920.

25 Rajagopal, R., Masse, D.I., Singh, G., 2013. A critical review on inhibition of anaerobic digestion process by excess ammonia. Bioresour. Technol. 143, 63241.

26 Ramos-Suárez, J.L., Martínez, A., Carreras, N., 2014. Optimization of the digestion process of Scenedesmus sp. and Opuntia maxima for biogas production. Energy Convers. Manage. 88, 1263-1270.

27 Santos-Ballardo, D.U., Rossi, S., Reyes-Moreno, C., Valdez-Ortiz, A., 2016. Microalgae potential as a biogas source: current status, restraints and future trends. Rev. Environ. Sci. Biotechnol. 15, 243-264.

28 Serrano, A., Siles, J., Martín, M., Chica, A., Estévez-Pastor, F., Toro-Baptista, E., 2016. Improvement of anaerobic digestion of sewage sludge through microwave pre-treatment. J. Environ. Manage. 177, 231-239. 
29 Song, Z., Zhang, C., 2015. Anaerobic codigestion of pretreated wheat straw with cattle manure and analysis of the microbial community. Bioresour. Technol. $186,128-35$.

30 Strömberg, S., Nistor, M., Liu, J., 2014. Towards eliminating systematic errors caused by the experimental conditions in Biochemical Methane Potential (BMP) tests. Waste Manage. 34, 1939-1948.

31 Webb, A.R., Hawkes, F.R., 1985. The Anaerobic-Digestion of Poultry Manure Variation of Gas Yield with Influent Concentration and Ammonium-Nitrogen Levels. Agric. Wastes 14, 135-156.

32 Wu, S., Ni, P., Li, J., Sun, H., Wang, Y., Luo, H., Dach, J., Dong, R., 2016. Integrated approach to sustain biogas production in anaerobic digestion of chicken manure under recycled utilization of liquid digestate: Dynamics of ammonium accumulation and mitigation control. Bioresour. Technol. 205, 7581.

33 Yen, H.W., Brune, D.E., 2007. Anaerobic co-digestion of algal sludge and waste paper to produce methane. Bioresour. Technol. 98, 130-4.

34 Yi, J., Dong, B., Jin, J., Dai, X., 2014. Effect of increasing total solids contents on anaerobic digestion of food waste under mesophilic conditions: performance and microbial characteristics analysis. PloS one 9, e102548.

35 Zhang, C., Xiao, G., Peng, L., Su, H., Tan, T., 2013. The anaerobic co-digestion of food waste and cattle manure. Bioresour. Technol. 129, 170-6. 


\section{Figure legends}

Fig. 1. Maximum methane yields of a) mono-substrates and b) co-substrates and c) codigestion effect compared to the maximum yields

Fig. 2. Methane production yield of the CSTR reactors fed with mono-substrate (microalgae) and co-substrate (80/20 on VS basis, microalgae/manure)

Fig. 3. Total VFA accumulation and $\mathrm{pH}$ fluctuation in the CSTR reactors 

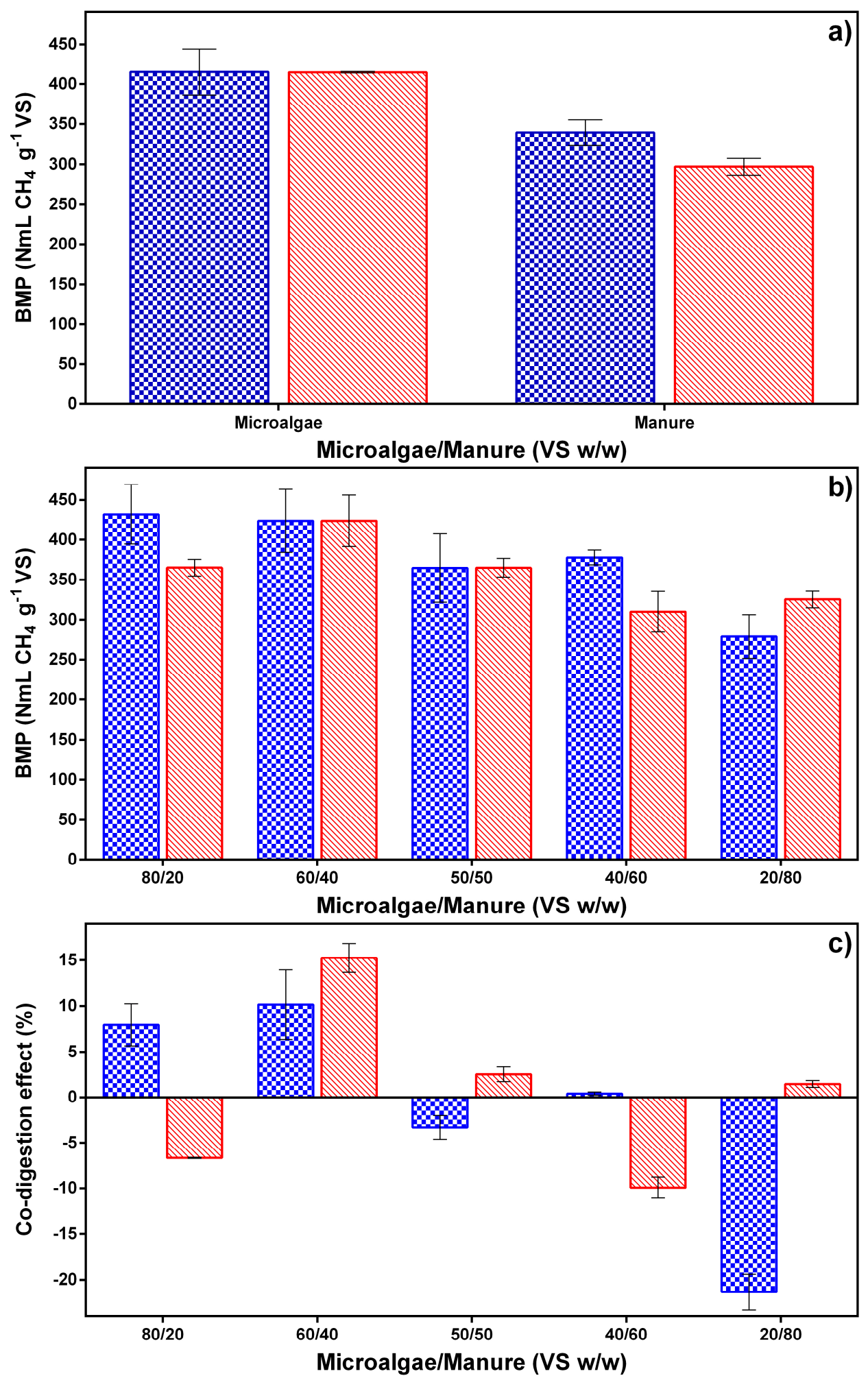

Organic loading: $2.33 \mathrm{~g}$ VS $\mathrm{L}^{-1} \quad$ Organic loading: $4.66 \mathrm{~g} \mathrm{VS} \mathrm{L}^{-1}$ 


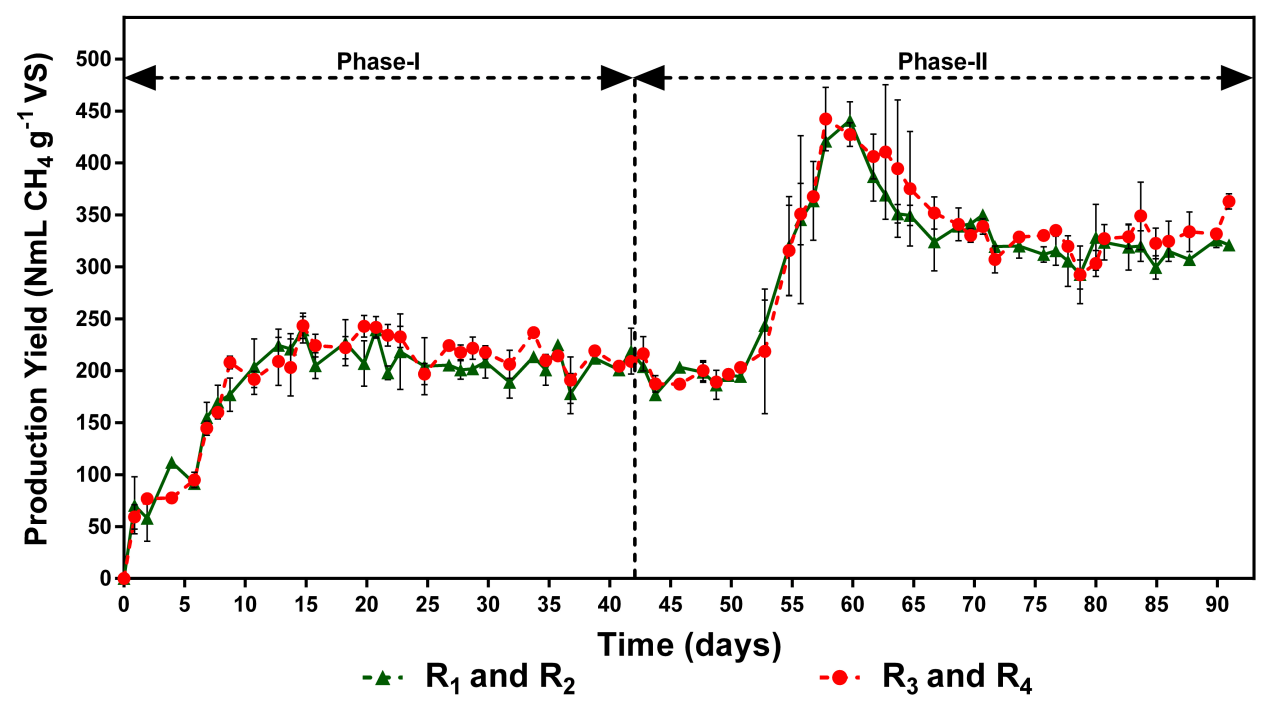

Fig. 2 


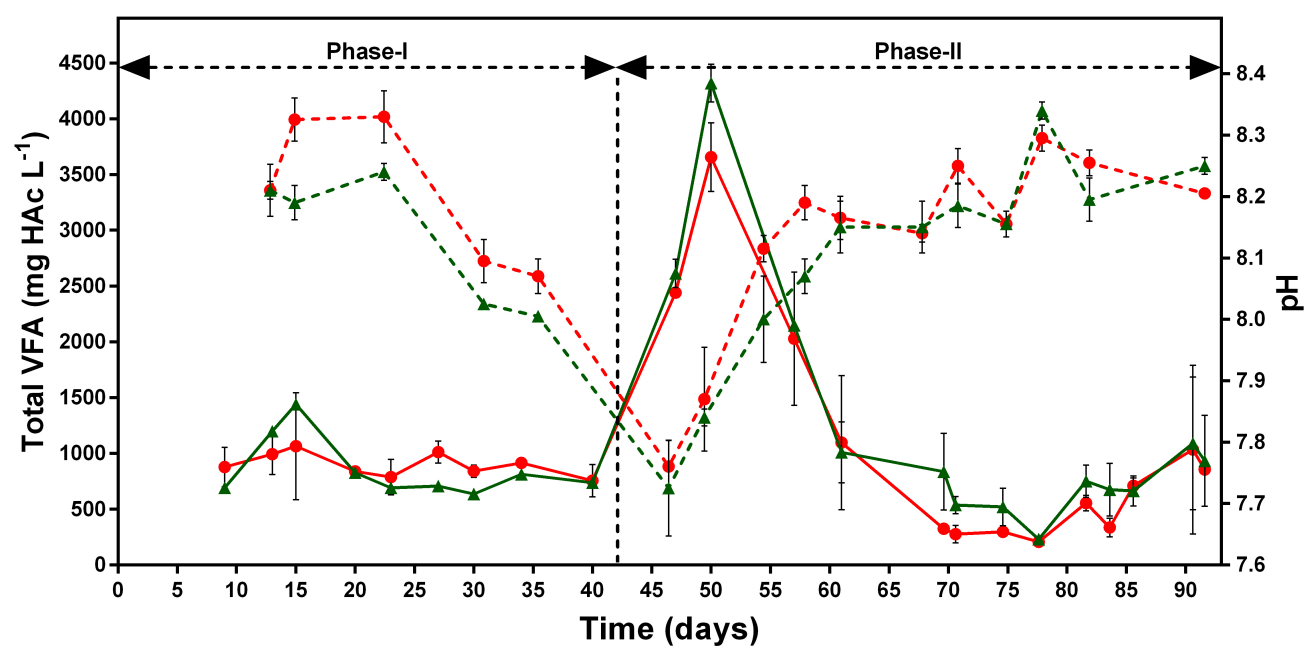

$\mp R_{1}$ and $R_{2}-V F A \quad \rightarrow R_{3}$ and $R_{4}-V F A \quad-k \cdot R_{1}$ and $R_{2}-p H \quad-\bullet \cdot R_{3}$ and $R_{4}-p H$

Fig. 3 
Table 1. Characteristics of the different substrates and inocula used in BMP and CSTR experiments.

\begin{tabular}{|c|c|c|c|c|}
\hline \multirow[t]{2}{*}{ Parameters } & \multicolumn{2}{|l|}{ Substrates } & \multicolumn{2}{|l|}{ Inocula } \\
\hline & Microalgae & Manure & Mesophilic & Thermophilic \\
\hline $\mathrm{TS}^{\mathrm{a}}\left(\mathrm{g} \mathrm{L}^{-1}\right)$ & $26.54 \pm 0.04$ & $32.90 \pm 0.02$ & $33.20 \pm 0.19$ & $31.60 \pm 0.04$ \\
\hline $\mathrm{VS}^{\mathrm{b}}\left(\mathrm{g} \mathrm{L}^{-1}\right)$ & $23.00 \pm 0.03$ & $23.00 \pm 0.04$ & $19.80 \pm 0.18$ & $20.80 \pm 0.04$ \\
\hline $\mathrm{TKN}^{\mathrm{c}}\left(\mathrm{g} \mathrm{N} \mathrm{L}^{-1}\right)$ & $2.37 \pm 0.03$ & $1.49 \pm 0.01$ & $5.01 \pm 0.13$ & $3.56 \pm 0.05$ \\
\hline Ammonia $\left(\mathrm{g} \mathrm{NH}_{4}{ }^{+}-\mathrm{N} \mathrm{L}^{-1}\right)$ & $0.57 \pm 0.06$ & $1.10 \pm 0.12$ & $4.58 \pm 0.02$ & $0.35 \pm 0.07$ \\
\hline $\operatorname{VFA}^{d}\left(\mathrm{mg} \mathrm{HAc} \mathrm{L}^{-1}\right)$ & $442.71 \pm 11.43$ & $8936.97 \pm 50.51$ & $76.08 \pm 5.75$ & $208.22 \pm 53.14$ \\
\hline \multicolumn{5}{|l|}{${ }^{\mathrm{a}} \mathrm{TS}=$ total solids } \\
\hline \multicolumn{5}{|l|}{${ }^{\mathrm{b}} \mathrm{VS}=$ volatile solids } \\
\hline${ }^{\mathrm{c}} \mathrm{TKN}=$ total Kjeldah & & & & \\
\hline
\end{tabular}


Table 2. Experimental set-up of mono- and co-digestion BMP experiments

\begin{tabular}{|c|c|c|c|}
\hline $\begin{array}{l}\text { VS microalgae/ } \\
\text { VS Manure }\end{array}$ & $\begin{array}{l}\text { Microalgae } \\
\left(g_{\mathrm{VS} \mathrm{L}}^{-1}\right)\end{array}$ & $\begin{array}{l}\text { Cattle manure } \\
\left(\mathrm{g} \mathrm{VS} \mathrm{L}^{-1}\right)\end{array}$ & $\begin{array}{l}\text { Organic loading } \\
\left(\mathrm{g} \mathrm{VS} \mathrm{L}^{-1}\right)\end{array}$ \\
\hline $100 / 0$ & 4.66 & 0.00 & 4.66 \\
\hline $80 / 20$ & 3.73 & 0.93 & 4.66 \\
\hline $60 / 40$ & 2.80 & 1.86 & 4.66 \\
\hline $50 / 50$ & 2.33 & 2.33 & 4.66 \\
\hline $40 / 60$ & 1.86 & 2.80 & 4.66 \\
\hline $20 / 80$ & 0.93 & 3.73 & 4.66 \\
\hline $0 / 100$ & 0.00 & 4.66 & 4.66 \\
\hline $100 / 0$ & 2.33 & 0.00 & 2.33 \\
\hline $80 / 20$ & 1.86 & 0.47 & 2.33 \\
\hline $60 / 40$ & & 0.93 & 2.33 \\
\hline $50 / 50$ & 1.17 & 1.17 & 2.33 \\
\hline $40 / 60$ & 0.93 & 1.40 & 2.33 \\
\hline $20 / 80$ & 0.47 & 1.86 & 2.33 \\
\hline $0 / 100$ & 0.00 & 2.33 & 2.33 \\
\hline
\end{tabular}


Table 3. Operational parameters in the different experimental phases of the four CSTR reactors

\begin{tabular}{|c|c|c|c|c|}
\hline & \multicolumn{2}{|c|}{ Phase-I (days 1-42) } & \multicolumn{2}{|c|}{ Phase-II (days 43-92) } \\
\hline & $R_{1}$ and $R_{2}$ & $\mathbf{R}_{3}$ and $\mathbf{R}_{4}$ & $\mathbf{R}_{1}$ and $\mathbf{R}_{2}$ & $\mathbf{R}_{\mathbf{3}}$ and $\mathbf{R}_{\mathbf{4}}$ \\
\hline Feedstock & Cattle manure & Cattle manure & Microa & Microalgae + \\
\hline $\operatorname{OLR}\left(g \operatorname{VS~L} \mathbf{L}^{-1} d^{-1}\right)$ & 1.13 & 1.13 & 0 & 2.09 \\
\hline Total Ammonia $\left(\mathrm{g} \mathrm{NH}_{4}{ }^{+}-\mathrm{N} \mathrm{L}^{-1}\right)$ & 1.10 & 1.10 & 43 & 4.40 \\
\hline
\end{tabular}




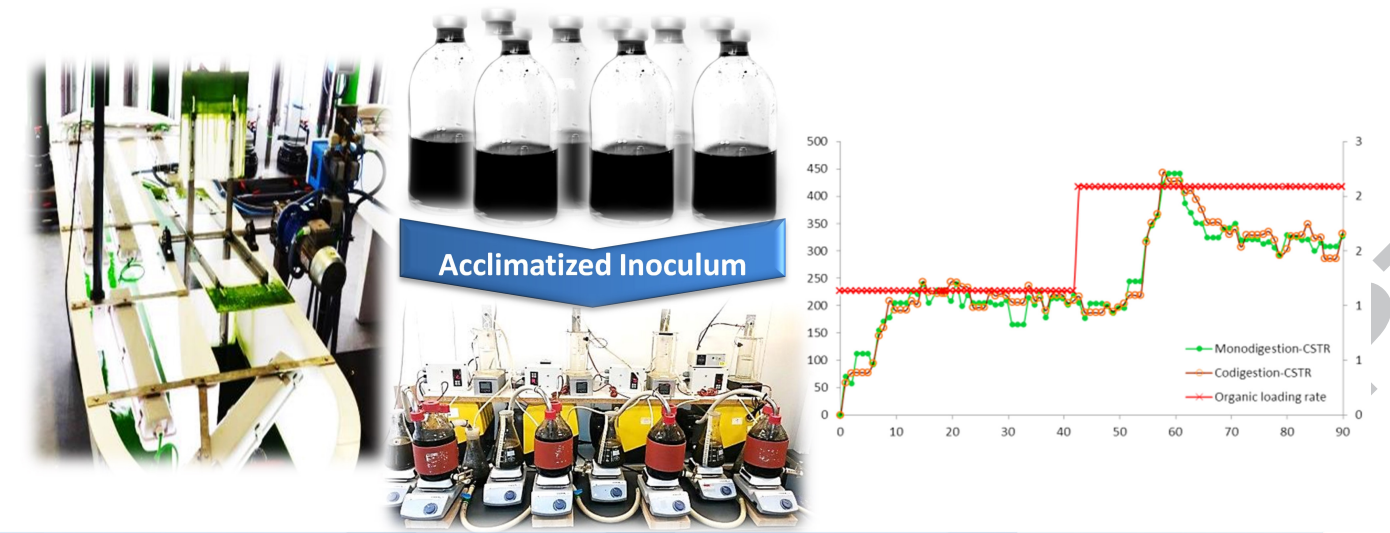

Graphical abstract 


\section{Highlights}

- Efficient $3^{\text {rd }}$ generation biogas production from protein-rich microalgae

- Synergistic co-digestion occurred only when "algae VS"/“cattle manure VS" > 1

- High methane yield for algae achieved when ammonia tolerant inoculum was used

- The highest yield was reached by coupling codigestion and ammonia tolerant inoculum 